\title{
Psychosocial wellbeing in war-affected Eastern Congolese adolescents
}

\author{
Cindy Mels \\ Promotor: Eric Broekaert \\ Vakgroep Orthopedagogiek, Universiteit Gent
}

Openbare verdediging: 25 mei 2010

Gedurende de voorbije decennia brachten gewijzigde dynamieken in oorlogsvoering een verhoogde impact teweeg op burgers, waaronder kinderen en adolescenten. Bijgevolg ontstond een toegenomen wetenschappelijke belangstelling voor de psychische gevolgen van politiek geweld, en de implicaties hiervan voor humanitaire psychosociale interventies. Ondanks de opmerkelijke vorderingen die reeds gemaakt werden in het documenteren van de prevalentie van psychische stoornissen bij door oorlog getroffen kinderen en adolescenten, alsook wat betreft het in kaart brengen van beïnvloedende risico- en protectieve factoren, blijft de huidige wetenschappelijke kennis begrensd door een aantal beperkingen.

Ten eerste, als gevolg van een overmatige focus op de directe effecten van oorlog op het psychologisch functioneren, zoals de gevolgen van traumatische blootstelling aan extreme gewelddaden, werden de indirecte en voortdurende gevolgen van politiek geweld zelden onderzocht. Dergelijke indirecte gevolgen zijn onder meer ontheemding en dagelijkse stressveroorzakende moeilijkheden (bijvoorbeeld, armoede en discriminatie). Ten tweede, de meeste studies naar de effecten van oorlog op kinderen en adolescenten werden uitgevoerd in vluchtelingenpopulaties in geïndustrialiseerde landen in Europa en Noord-Amerika. Echter, deze bevindingen kunnen niet simpelweg gegeneraliseerd worden naar door oorlog getroffen populaties die aanhoudend in oorlogsgebied verblijven, zoals zij die nooit vluchtten, of mensen op de vlucht in hun eigen land (intern ontheemden). Ten derde, de huidige wetenschappelijke kennis is onderworpen aan een vertrouwen in Westerse psychiatrische constructen en onderzoeksinstrumenten, zonder dat de validiteit daarvan bewezen is voor het gebruik in andere culturen, en zonder ruimte te laten aan de lokale betekenisverlening en culturele of contextuele specificaties. Tenslotte, als gevolg van deze bovenvernoemde restricties bleef de bijdrage van de wetenschap aan het humanitaire veld en de ontwikkeling van lokaal betekenisvolle interventiestrategieën ter promotie van de psychische gezondheid van kinderen en jongeren in conflictgebieden beperkt.

Met deze beperkingen in het achterhoofd, tracht dit proefschrift het psychosociaal welzijn en de daarbij betrokken risico- en protectieve factoren van door oorlog getroffen adolescenten in kaart te brengen, met een bijzondere focus op een aantal tot nu toe zelden onderzochte terreinen. Met name de specifieke situatie in Sub-Sahara Afrika, interne ontheemding, en de indirecte gevolgen van langdurig conflict komen aan bod. Geleid door een sociaal-ecologisch theoretisch kader en ideeën uit het sociaal constructivisme, 
trachten we dit te doen op een cultureel valide manier, met relevantie voor de praktijk, en voortbouwend op de beschikbare lokale kennis en mogelijkheden. De onderzoekssetting van deze studie is Ituri, een provincie in het oosten van de Democratische Republiek Congo, getroffen door etnisch geweld en aanhoudend gewapend verzet door militiebewegingen sinds 1999 .

In een eerste studie trachten we de voorwaarden te scheppen voor lokaal en cultureel relevant onderzoek. Deze studie omvat focusgroepdiscussies en individuele interviews met 66 lokale actoren uit het jeugdwelzijnswerk. Deze data laten ons toe om de lokale context en de daarin betrokken determinanten voor het psychosociaal welzijn van adolescenten beter te begrijpen (hoofdstuk 2). Een aantal specifieke uitdagingen als gevolg van de oorlog komen daarin naar voor, zoals de gewijzigde rollen voor adolescenten in de gemeenschap, gewijzigde familiale relaties, beperkte socio-economische vooruitzichten, gewijzigde waarden en normen in de gemeenschap, en een disfunctionerend juridisch en onderwijssysteem. Bovendien bezorgen deze data ons een kader om de huidige humanitaire agenda met betrekking tot psychosociale hulpverlening in door oorlog getroffen gebieden - weerspiegeld in de Inter-Agency Standing Committee (IASC) Guidelines on Mental Health and Psychosocial Support in Emergency Settings (2007) - te evalueren. We concluderen dat de door het IASC voorgestelde humanitaire multi-level aanpak waardevol is, maar onvoldoende aandacht schenkt aan voortdurende processen van sociale verandering, die mee het psychosocial welzijn vormgeven. Hierbij aansluitend maken we een aantal suggesties voor een verdere verfijning van de humanitaire richtlijnen voor psychosociale interventie.

Daarnaast bezorgt deze studie ons eveneens data die ons toelaten om de culturele variantie van DSM-IV gebaseerde concepten van psychische symptomatologie te onderzoeken in de Oost-Congolese context. Lokale hulpverleners werden bevraagd over hun ervaringen met adolescenten en de daarin geobserveerde symptomen in navolging van de oorlog. Deze symptomen werden vervolgens vergeleken met deze bevraagd in op DSM-IV gebaseerde gestandaardiseerde vragenlijsten, namelijk de Hopkins Symptoms Checklist - 37 voor Adolescenten (HSCL-37A) en de Impact of Event Scale - Revised (IES-R). Er blijkt vooral een culturele variantie te bestaan in de symptoombeelden betreffende externaliserende gedragsproblemen en depressie. De onderzochte op DSM-IV gebaseerde symptomen van posttraumatische stress stoornis blijken solide voor gebruik in Oost-Congolese adolescenten, echter, de theoretisch veronderstelde drievoudige factorstructuur werd niet bevestigd in onze kwantitatieve analyse van de aangepaste IES-R. Daarnaast blijken de psychometrische kwaliteiten van de aangepaste IES-R en HSCL-37A vergelijkbaar met deze omschreven in de literatuur (hoofdstuk 3).

In een tweede studie worden de prevalentie van deze symptomen en de geassocieerde risico- en protectieve factoren onderzocht in een geclusterde steekproef van I,046 secundaire school leerlingen ( 13 tot 12 jaar). Hoofdstuk 4 behandelt de indrukwekkend hoge mate van traumatische blootstelling gerapporteerd door de adolescenten in deze studie (95.0\%), die bovendien afhankelijk blijkt van geslacht, leeftijd, woongebied en ouderlijk overlijden. Daarnaast bevestigt deze studie het vaak omschreven dosis-effect 
van traumatische blootstelling op de symptoomprevalentie van posttraumatische stress. Echter, uit de analyses in hoofdstuk 5 blijkt dat een belangrijk deel van de variantie in posttraumatische stresssymptomen eveneens kan verklaard worden door een effect van dagelijkse stressveroorzakende moeilijkheden. Met betrekking tot internaliserende problemen, blijkt het voornamelijk de interactie van zowel traumatische als dagelijkse stressoren te zijn die de symptoomprevalentie bepaalt. Daarenboven lijken hoofdzakelijk deze stressoren de vastgestelde prevalentieverschillen naargelang de ontheemdingsachtergrond van adolescenten (blijvend ontheemd, tijdelijk ontheemd maar hergevestigd, nooit ontheemd) te verklaren. Uit deze analyses blijkt dat, onafhankelijk van eerdere ontheemding of traumatische blootstelling, een reductie van symptomen mogelijk kan bewerkstelligd worden door het verbeteren van de dagelijkse levensomstandigheden van deze adolescenten (bijvoorbeeld, door de preventie van nieuw geweld, het stimuleren van socio-economische en onderwijskansen, familiale en gemeenschapsrelaties, etc.). Hoofdstuk 6 verkent de copingstrategieën die Oost-Congolese adolescenten gebruiken. Deze strategieën blijken te variëren naargelang woongebied en de traumatische en dagelijkse stressoren waar de adolescenten mee te maken hebben. In tegenstelling tot wat algemeen verondersteld wordt, brengt onze studie aan het licht dat door oorlog getroffen adolescenten mogelijks baat kunnen hebben bij het gebruik van ontwijkende/zich terugtrekkende copingstrategieën, in het bijzonder oudere leeftijdsgroepen.

Een derde studie tracht de lokale context voor psychosociale hulpverlening aan adolescenten in kaart te brengen. Enerzijds werden de door adolescenten ervaren psychosociale interventiebehoeften onderzocht aan de hand van groepsdiscussies met 4I jongeren in Ituri. Hieruit blijkt dat - naast andere gemeenschapsnetwerken zoals kerken - nietgouvernmentele organisaties (NGO's) een belangrijke bijdrage kunnen leveren aan een verhoogd psychosociaal welzijn van jongeren in de gemeenschap, door de voorziening van basisbehoeften (materieel en nutritioneel), opleiding, juridische en medische bijstand en meer specifieke psychologische ondersteuning. Daarnaast zorgden interviews met vertegenwoordigers van alle 23 lokale NGO's voor kwetsbare jeugd in Ituri voor een inventaris van al hun psychosociale initiatieven, hun ervaren interventie-sterktes, ondervonden hinderpalen en daaruit volgende aanbevelingen. Met deze data trachten we in hoofdstuk 7 de concrete context te schetsen voor verdere psychosociale programmering in Ituri, die de ervaren behoeften van de doelgroep incorporeert en die verder bouwt op de reeds aanwezige lokale ervaring, kennis en middelen.

In de algemene discussie (hoofdstuk 8) brengen we de belangrijkste onderzoeksbevindingen samen, en bespreken we hun implicaties voor de bevordering van het psychosociale welzijn van adolescenten in Ituri in Oost-Congo. Ten slotte bespreken we de beperkingen van de studies in deze thesis en brengen een aantal suggesties voor verder onderzoek naar voor. 